\title{
Industry Integration Helps Market Expansion of Guizhou Liquor Industry
}

\author{
Wei Dong \\ Big Data Application and Economics Institute \\ Guizhou University of Finance and Economics \\ Guiyang, China
}

\author{
Heping $\mathrm{Xu}$ \\ Western Modernization Research Center \\ Guizhou University of Finance and Economics \\ Guiyang, China
}

\begin{abstract}
China's liquor industry has entered a period of deep adjustment and faces the dilemma of reopening the market. Guizhou, as a major province in liquor production, is representative in the study of liquor market expansion. In order to study how to develop the market of Guizhou liquor, this paper uses the date of Guizhou liquor industry in 2017 to quantitatively analyze the development status of Guizhou liquor industry. The paper summarizes the problems existing in the market expansion, and put forward countermeasures based on the theory of industrial integration. For Guizhou, it is suggested to strengthen the integration between liquor industry and the Internet, tourism, culture and exhibition industry, so as to open up channels for liquor sales and promote the stable development of liquor industry.
\end{abstract}

Keywords-industrial integration; liquor industry; market expansion; Guizhou liquor

\section{INTRODUCTION}

Under the background of the new normal economy and a series of policies issued by the government, the liquor industry in China is facing pressure of development, and the development of the liquor industry market is hindered by the downturn. Faced with the new economic situation, the major liquor-producing provinces should have insight into the market reorientation. As the production place of Maotai liquor and the major liquor-producing provinces, Guizhou should adjust the market in time to open up a new round of market. Taking Guizhou as the research object, this paper puts forward some suggestions on the market expansion of liquor-making industry from the perspective of industry integration.

In 1978, Nicholas Negreouponte of MIT discovered that the intersection of computer, printing and broadcasting industries was the fastest growing and most innovative place, thus opening up the study of industrial convergence [1]. Industrial integration has the following characteristics: bringing innovation, occurring in the industrial intersection and marginal zone, is a dynamic process. Industrial integration can improve resource utilization efficiency, enhance industrial competitiveness, promote industrial structure optimization and upgrading, and promote the emergence of new industries to form new economic growth points [2]. The existing literature on the integrated development of liquor industry in China is less and focuses on the integration of liquor industry and tourism. Zhang Fengting and $\mathrm{Xu}$ Zhe (2018) studied the feasibility of the integrated development of Sichuan liquor industry and tourism culture industry from the perspective of

Fund Project: National Social Science Fund Project "Comparative Study of China - America- Europe Urbanization History and Model from the

Perspective of Resources" (Code: 15XJL018) industrial integration [3]. Zhang Fengting and Xu Zhe (2018) also proposed four methods for the integrated development of Sichuan liquor industry and tourism culture under the background of supply-side reform [4]. This paper puts forward innovative ideas on the integration of liquor and other industries.

The liquor industry has strong correlation with upstream and downstream industries, and its production and sales links involve related fields such as agriculture, service industry and manufacturing industry [5]. Based on the great potential of liquor industry and the high degree of integration with other industries, it is very easy to integrate with related industries and form a new industrial format. Linkage development can effectively expand liquor sales, avoid strong competition in the liquor market, and seize market share in the unexplored "Blue Sea".

\section{BASIC SituATION OF LIQUOR INDUSTRY DEVELOPMENT IN GUIZHOU}

Guizhou is a major province of liquor production. Liquor overtook coal as the first pillar industry in Guizhou in 2015, and it is also a dominant characteristic industry. As early as the pre-Qin period, Guizhou began to brew liquor. Because of its unique geographical conditions and winemaking climate, it became the best place to produce Maotai-flavor liquor. The province has 14 well-known Chinese trademarks such as Maotai, Xijiu and Guotai. Four liquor enterprises such as Yaxi and Lai Yongchu have won the title of Chinese Old Brand. Guizhou liquor production ranks eighth in China, but its total sales are in the top three. The total profit has been ranked first in the country for a long time. The liquor industry is green and pollution-free, with high profitability and has strong ability to promote employment. The outstanding advantages of liquor industry are the key development industries in Guizhou at this stage.

In recent years, the scale of Guizhou liquor industry has expanded rapidly, and the added value of liquor has become the first in Guizhou industry. Liquor production has increased rapidly in the past five years, with an average annual increase of $9.37 \%$. It reached 452,000 kiloliters in 2017, ranking eighth in the country. Among them, the total liquor production of Maotai Group was 127,000 kiloliters, up 26.5\% year-on-year, accounting for $28.1 \%$ of the province's liquor production. The industrial added value was 66.42 billion yuan, an increase of $49.5 \%$ over the previous year. The total profit of liquor sales 
continued to grow. In 2017, the total sales revenue of Liquor Enterprises above the provincial scale reached 82.86 billion yuan, an increase of $40.4 \%$ over the same period last year. In 2017, the total profit of Guizhou alcoholic drinks was 42.03 billion yuan, an increase of 59.9\% over the previous year. The total profit and export earnings of Guizhou alcoholic drinks were 2.5 billion yuan, ranking first in the country. Among them, Maotai Group completed a total profit of 40.34 billion yuan, an increase of $60.7 \%$ over the previous year. The main indicators of Guizhou liquor industry in 2013-2017 are shown in Table I. The relevant data are from the Guizhou Statistical Yearbook in 2014-2018.

TABLE I. MAIN INDICATORS OF GUIZHOU LIQUOR INDUSTRY IN 2013-2017

\begin{tabular}{|c|c|c|c|c|c|c|c|c|c|c|c|}
\hline \multirow[b]{2}{*}{ Indicator name } & \multirow[b]{2}{*}{$\begin{array}{c}\text { Unit of } \\
\text { measurement }\end{array}$} & \multicolumn{2}{|c|}{ Year 2013} & \multicolumn{2}{|c|}{ Year 2014} & \multicolumn{2}{|c|}{ Year 2015} & \multicolumn{2}{|c|}{ Year 2016} & \multicolumn{2}{|c|}{ Year 2017} \\
\hline & & $\begin{array}{l}\text { Absolute } \\
\text { number }\end{array}$ & $\begin{array}{l}\text { Increase } \\
\text { over the } \\
\text { previous } \\
\text { year (\%) }\end{array}$ & $\begin{array}{l}\text { Absolute } \\
\text { number }\end{array}$ & $\begin{array}{l}\text { Increase } \\
\text { over the } \\
\text { previous } \\
\text { year (\%) }\end{array}$ & $\begin{array}{l}\text { Absolute } \\
\text { number }\end{array}$ & $\begin{array}{l}\text { Increase } \\
\text { over the } \\
\text { previous } \\
\text { year (\%) }\end{array}$ & $\begin{array}{c}\text { Absolute } \\
\text { number }\end{array}$ & $\begin{array}{l}\text { Increase } \\
\text { over the } \\
\text { previous } \\
\text { year (\%) }\end{array}$ & $\begin{array}{l}\text { Absolute } \\
\text { number }\end{array}$ & $\begin{array}{l}\text { Increase } \\
\text { over the } \\
\text { previous } \\
\text { year (\%) }\end{array}$ \\
\hline $\begin{array}{c}\text { Output of } \\
\text { Liquor-making } \\
\text { Enterprises } \\
\text { above scale } \\
\end{array}$ & Kiloliter & 323,800 & 20.4 & 346,900 & 12.6 & 427,900 & 11.1 & 490,000 & 10.5 & 452,000 & -7.75 \\
\hline $\begin{array}{c}\text { Industrial } \\
\text { Value Added }\end{array}$ & Billion & 470.79 & 15.0 & 572.91 & 13.0 & 662.95 & 9.8 & 735 & 11.6 & 804.2 & 12.9 \\
\hline $\begin{array}{l}\text { Main Business } \\
\text { Income } \\
\end{array}$ & Billion & 468.58 & 14.3 & 495.45 & 6.1 & 563.41 & 11.5 & 635.8 & 21.1 & 828.6 & 40.4 \\
\hline Total profit & Billion & 336.86 & 11.3 & 335.09 & 0.3 & 350.14 & 3.6 & 263.4 & 11.2 & 420.3 & 59.9 \\
\hline
\end{tabular}

From the perspective of the development of Guizhou liquor industry in 2013-2017, the production of liquor has increased steadily. From 328,300 kiloliters in 2013 to 452,000 kiloliters in 2017, it reached a maximum of 490,000 kiloliters in 2016. In 2017, due to the impact of macro economy, the output has fallen, and generally showed an upward trend. The proportion of Guizhou liquor production in the whole country is also increased year by year, from 2.64\% in 2013 to 3.77\% in 2017. This shows that the development of liquor in Guizhou is fast, and the production capacity and output increase faster than other provinces. On the other hand, the ranking of output in 2017 rose from ninth in 2016 to eighth, indicating that Guizhou liquor has made steady progress under the deep adjustment of liquor industry. The proportion of Guizhou liquor production in 2013-2017 is shown in Fig. 1.

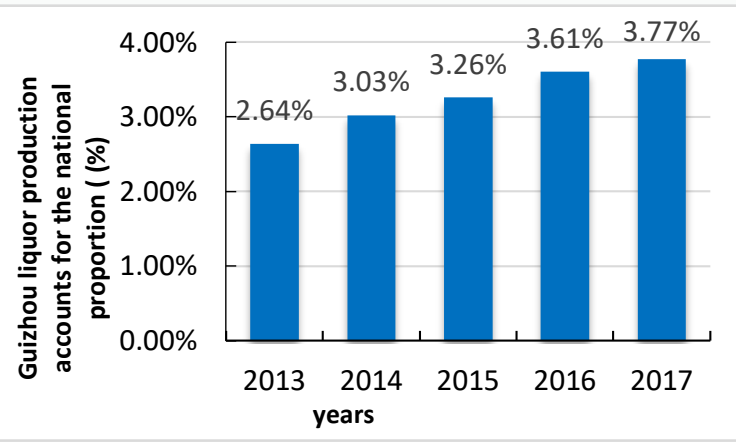

Fig. 1. Guizhou wine production accounted for the national proportion in 2013-2017

As shown in the Fig. 2, there is a big gap between Guizhou and other major liquor-producing provinces. In 2017, the total output of national liquor (65 degrees) was 11.986 million kiloliters. Sichuan, Henan and Shandong were the top three provinces in liquor production, with the output of 3,723,800 kiloliters, 1,149,100 kiloliters and 1,062,700 kiloliters respectively. The output of the three provinces accounted for
49.54\% of the national output. Liquor production in Guizhou Province is 452,000 kiloliters, accounting for only $3.77 \%$ of the national output. In 2017, the output and proportion of major liquor production provinces in China are shown in Table II and Fig. 2.

TABLE II. PRODUCTION AND PROPORTION OF MAJOR WHITE WINE PRODUCING PROVINCES IN 2017

\begin{tabular}{|c|c|c|c|}
\hline Ranking & Province & $\begin{array}{r}\text { Liquor production (65 } \\
\text { degrees) }\end{array}$ & $\begin{array}{c}\text { National kiloliters } \\
\text { share }\end{array}$ \\
\hline & nationwide & 1198.06 & $100 \%$ \\
\hline 1 & Sichuan & 372.38 & $31.08 \%$ \\
\hline 2 & Henan & 114.91 & $9.59 \%$ \\
\hline 3 & Shandong & 106.27 & $8.87 \%$ \\
\hline 4 & Jiangsu & 92.35 & $7.71 \%$ \\
\hline 5 & Jilin & 77.77 & $6.49 \%$ \\
\hline 6 & Hubei & 61.98 & $5.17 \%$ \\
\hline 7 & Heilongjiang & 57.78 & $4.82 \%$ \\
\hline 8 & Guizhou & 45.2 & $3.77 \%$ \\
\hline 9 & Anhui & 43.93 & $3.67 \%$ \\
\hline 10 & Beijing & 33.81 & $2.82 \%$ \\
\hline 11 & Other & 191.68 & $16.00 \%$ \\
\hline
\end{tabular}

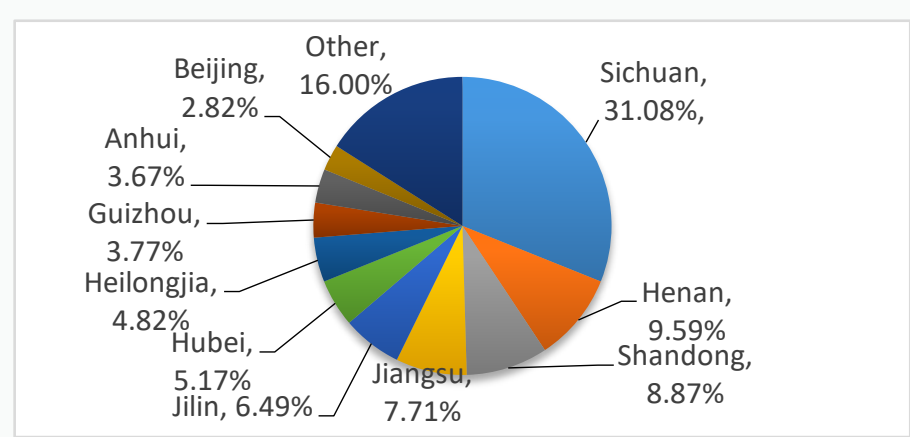

Fig. 2. Output Proportion of Main Liquor Producing Provinces in 2017 


\section{ThE MAIN PROBLEMS IN THE EXPANSION OF GUIZHOU LIQUOR INDUSTRY MARKET}

\section{A. Old Sales Concept and Tradition Operation Mode}

The original sales concept is "wine fragrance is not afraid of deep alley". If there is good wine, the consumers will naturally smell the fragrance and come. However, in today's society, there are not only good wine but also good marketing methods. We should bring liquor alleys to consumers and provide them with all kinds of needs. Now the growth of liquor industry not only depends on quality, but also on marketing strategy and brand building. Most liquor-making enterprises in Guizhou are dominated by traditional distribution, direct operation and monopoly. The sales mode is still in a passive state, following the mode of "General Agent + Distribution". The management concept needs to be updated and the management mode needs to keep pace with the times. Guizhou liquor-making enterprises lack market operation and pioneering ability, lack of demand within the province and weak competitiveness outside the province, resulting in narrow market sales and insufficient power in the industry.

\section{B. Low market share of Maotai-flavor Liquor}

The proportion of Maotai-flavor liquor in the market is low, and consumers' awareness is still insufficient for Maotai-flavor liquor. $70 \%$ of the domestic liquor market was occupied by Luzhou-flavor liquor, followed by Fen-flavor liquor and Mi-flavor liquor, which accounted for $15 \%$ and $7 \%$ respectively. Maotai-flavor liquor only accounts for $5 \%$ of the market share, which is relatively low. Guizhou is the main producing area of Maotai-flavor liquor, and has many Maotai-flavor liquor brands, among which Maotai is the model of Maotai-flavor liquor. In addition, Xi Jiu, Bei Jiu, Zhen Jiu and Qianchun Jiu also belong to Maotai-flavor liquor. Maotai-flavor liquor has strong sauce flavor, delicate entrance, mellow taste and long fragrance after drinking. The traditional brewing technology is adopted in the production process, which has a long-brewing cycle and less alcohol production. Maotai-flavor liquor has little stimulation to human body, can soften blood vessels, prevent cardiovascular diseases, and has the effect of health care and liver protection. Long-term drinking is beneficial to human health. The characteristics of Maotai-flavor liquor are not widely recognized, so that consumers fail to form the recognition and value of Maotai-flavor liquor production process.

\section{Lock of Industrial Integration}

The integration of liquor industry with other industries is not deep, and the industrial chain is not complete. Guizhou liquor culture has a long history. It only pays attention to the propaganda of liquor culture, but fails to involve people's life style, cultural taste and other higher-level interpretation. There is a lack of industrial tourism demonstration zones and the deep integration of liquor and tourism in Guizho. The cooperation between liquor industry and related industries needs to be strengthened. Liquor industry chain is out of touch, and the producers and distributors are separated from each other. Their respective pursuit of maximum benefits can't be based on the long-term development of the industry, which seriously affects enterprise financing and market expansion.

\section{SUGGESTIONS ON THE EXPANSION OF GUIZHOU LIQUOR MARKET BASED ON THE PERSPECTIVE OF INDUSTRIAL INTEGRATION}

\section{A. Promoting Online Sales through Internet Platform}

The liquor sales channel no longer rely on the single-line "General Agent + Distribution" mode, should be transformed into the "Chain operation + Internet" mode. The introduction of the Internet into people's lives has changed the original purchase method and used the Internet for online sales. It is an innovation in communication between liquor producers and consumers, and it has brought about changes in the sales market. The Internet is not only an innovative marketing method, but also brings a broad market. More importantly, it provides a channel for the promotion of liquor value brand.

Guizhou liquor enterprises have limited market capacity due to small demand in the province, while limited market expansion outside the province, weak competitiveness and less room for liquor market. On the contrary, the "blue sea" of the e-commerce line has broken through geographical restrictions, reduced a large number of store rentals and labor costs, and has huge market potential in the face of a wide range of consumers at home and abroad. At present, the annual output value of liquor industry in China has reached 800 billion yuan, and online transaction is only 20 billion yuan, accounting for only $2.5 \%$ of the annual output value. Compared with the clothing industry, which accounts for $20 \%$ of online trading, the liquor industry still has a lot of room for development. Guizhou liquor enterprises should make full use of "Internet +" to promote marketing and build a liquor e-commerce platform.

\section{B. Strengthen the Integration of Liquor Industry and Tourism}

Guizhou has a unique natural landscape and the tourism industry is rich and diverse. The integration of liquor industry and tourism industry will bring new opportunities and development to the liquor industry. Strengthen the integration of liquor industry and tourism, vigorously promote the ecological tourism of liquor-producing areas in Chishui River Valley. To create wine culture tourism based on wine tasting and drinking, and industrial tourism based on Maotai-flavor liquor production process experience. The main producing areas of liquor in Guizhou should take the integration of liquor and tourism as the concept, create folk wine villages, inn-style wineries and experience-style wine houses, and provide one-stop service for tourists. In the travel, the basic functions of sightseeing, vacation, leisure and entertainment, catering and accommodation will be improved from five aspects of eating, living, traveling, shopping and entertainment.

Focus on the tourist experience, so that tourists can fully understand the production of liquor. In the process of tourists' sightseeing, wine making skills will be displayed on site, wine tasting and drinking knowledge will be popularized, modern application of liquor culture will be interpreted, and "experiential marketing" mode of liquor will be initiated to create a leisure and vacation tourism destination featuring liquor culture. We should not only sell wine, but also invite consumers in, giving full play to the integration of liquor and tourism. Vigorously develop liquor tourism products, making it easy to carry and exquisite packaged. We can start with 
packaging content, different alcohol concentration and different series of commodities to carry out combined sales in order to meet the needs of different consumers.

\section{The Integration of Liquor Industry and Culture}

Guizhou has a long history of liquor-making and rich liquor culture since ancient times. Historical and cultural heritage can be well used to promote the growth of liquor industry. The history of wine making in Guizhou can be traced back to the pre-Qin Dynasty. Wine utensils were found in the relics unearthed from the tombs of the Han Dynasty in northern Guizhou. It is clearly recorded in the historical records that "Guizhou people are good at brewing" is a good reputation for Guizhou people, indicating that the ancient Guizhou people's brewing skills have reached a certain height [6]. The ancient liquor-making techniques have been handed down so far, which is the most powerful evidence to prove the ancient liquor culture in Guizhou.

Integrate wine culture with local ethnic and folk culture. Guizhou is a multi-ethnic province. In the development of history, people of all ethnic groups regard wine as an indispensable part of life, forming interesting drinking rituals and customs, known as "Girl's Wine", "Eight-character Wine", "Barrier Wine" and so on. Guizhou should integrate national culture with liquor industry, implant the liquor into the folk culture, make people feel the charm of liquor culture while appreciating the folk customs of different nationalities, cultivate liquor market deeply and expand consumption space.

To create a batch of cultural works to publicize Guizhou liquor and Maotai Liquor, and to evolve the cultural customs inherited from Guizhou liquor into the liquor ceremony and liquor customs suitable for modern people. Based on the historical stories about the development of Guizhou wine, a series of related film and television works and novel readings are created to show the origin and history of Guizhou wine, so as to promote the development of liquor industry through cultural communication. Deeply excavate the cultural connotation of Guizhou liquor, keep up with the pace of the times, deeply interpret the modern meaning of liquor culture in terms of lifestyle, cultural taste, leisure and health. Depending on the popularity of Maotai, we should deeply explore the cultural connotation of the brand and speed up the construction of Maotai Ancient Town Cultural Industrial Park. Cultivating consumers' brand preference from multiple perspectives, forming quality recognition and value affirmation of Guizhou liquor, and enhancing brand loyalty and reputation.

\section{The integration development of liquor industry and} exhibition industry

Through the exhibition, industry to promote the development of liquor industry. The exposition and exhibition center provides a platform for display and trade of liquor products and a place for appreciation and communication of people who love liquor. With the gradual expansion of the liquor industry, the corresponding exhibition gradually forms part of the liquor industry to assist the development of the liquor industry. Continue to encourage the holding of China International Wine Expositions, and actively guide enterprises to participate in wine exposition, Canton Fair, trade fairs and other activities. Carry out liquor marketing and investment promotion activities in an all-round way, and open the international market by holding international liquor exhibitions.

Strive to create high-level exhibitions. Hold international famous wine expositions and liquor tasting meetings, set up large-scale and high-quality liquor exhibition centers, gradually expand the influence of Guizhou in the national liquor market, and support the cultural card of "the capital of national liquor". To guide the entry of high-end customers and enhance the promotion of Guizhou Maotai-flavor liquor through high-level exhibition in liquor industry, industry communication and wine tasting festivals. At the same time, the exposition will be used to develop the exhibition economy, hold wine tasting, boxing, gourmet food, customs clearance, wine-making process experience to enhance the participation of visitors, and further publicize the history and culture of Guizhou liquor, so as to expand liquor sales channels and enhance market share.

\section{SUMMARY}

As China's liquor industry is subject to macro policies and enters a period of deep adjustment, Guizhou's liquor industry is faced with a series of problems, such as narrow market, outdated sales concept and low degree of industrial integration, which requires efforts in market expansion. The liquor industry has a high correlation with other industries. Guizhou can integrate the liquor industry with the Internet, tourism, culture and exhibition industry to develop into a new strategy to expand the market and drive the booming economic development.

\section{REFERENCES}

[1] Lu Fucai, "Industrial Economics," M. Shanghai, Fudan University Press, 2013. (In Chinese)

[2] Gong Sanle, Xia Fei, "Industrial Economics," M.Chengdu, Southwest University of Finance and Economics Press, 2018. (In Chinese)

[3] Zhang Fengting, Xu Zhe,"On the Integration and Development of Sichuan Liquor Industry and Tourism Culture Industry," J.Liquor-making Science Technology, pp.123-126. September 2018. (In Chinese)

[4] Zhang Fengting, Xu Zhe,"Research on the Way of Integrating Tourism Culture into Liquor Industry under the Background of Supply-side Reform,"J.Liquor-making Science Technology, pp.113-117, January 2018.(In Chinese)

[5] Hou Yajing."Research on the Optimization of China's Liquor Industry Cluster and Industry Chain,"D.Tianjin: Tianjin University of Technology, 2011. (In Chinese)

[6] He Qiong,"Linkages between Liquor Culture and Economic Development of Liquor Industry in Guizhou," J.Liquor-making Science Technology, pp.115-118, December 2016. (In Chinese) 